\title{
THE USE OF ERGONOMIC ANALYSIS METHODS AS SUPPRT IN THE ASSESSMENT OF OCCUPATIONAL RISK IN THE POSITION OF A SELLER IN A SMALL GROCERY STORE (POLAND)
}

doi: $10.2478 /$ czoto-2021-0022

Date of submission of the article to the Editor: 29/11/2020

Date of acceptance of the article by the Editor: 20/03/2021

Agata Kielesińska ${ }^{1}$ - orcid id: 0000-0001-9974-7961

1 Czestochowa University of Technology, Poland

\begin{abstract}
The profession of a seller (especially in small grocery stores) does not enjoy a social respect. The reasons for this are, above all, low requirements, low salary and difficult working conditions. In addition, too little attention is paid in the literature to this profession from the point of view of safety and hazards at work. However, the problem of working conditions in the position of a salesman is an important issue concerning a very large number of people. The paper deals with this difficult topic by describing selected methods of ergonomic analysis and using them to assess occupational risk at the seller's workplace. In the paper, the results of the Ergonomic Checkpoint List, as well as the results of questionnaire surveys are presented. All the results are related to the possibility of proper identification and the probability of hazards occurrence in the position of a seller.
\end{abstract}

Keywords: occupational risk, musculoskeletal load, risk assessment methods, work safety, Ergonomic Checkpoint List

\section{INTRODUCTION}

The problem of working conditions as a salesman is an important issue that concerns a very large number of people. According to the report by PNB and Delotte, commercial companies create a very large number of jobs - e.g. in Poland, almost 2 million jobs. A further 1.6 million people are employed in the trade-related sectors. It accounts for over a quarter of the total workforce, a large part of which is employment in small and large grocery stores - in Poland about 184 thousand people. According to Eurostat data (Eurostat Report, 2020), with a comparable number of retail stores in France, there are 600,000 more people working, and more than twice as many in the UK. It is caused precisely by low wages and high mental and physical burdens (Report, 2020; Sas, 2020).

The purpose of the paper is to characterize the risks present in the sales desk and to perform an ergonomic assessment using the Ergonomic Checkpoints List. The paper also includes the results of surveys conducted among people employed as salesmen in a grocery store. 


\subsection{Legal regulations concerning occupational risk}

Occupational risk assessment at the workplace is the responsibility of every employer under the provisions of the Labor Code and the Regulation of the Minister of Labor and Social Policy on general health and safety at work regulations of September 26, 1997 Regulation of the Minister of Labor and Social Policy of September 26, 1997 on general occupational health and safety regulations supported by international standards (Holubova, 2016; Rozporządzenie Ministra Pracy i Polityki Socjalnej, 1997). The provisions of the Labor Code impose an obligation on the employer to inform employees about the level of occupational risk, sources of danger, effects and protective methods. This provision obliges the employer to make and document the occupational risk and take the necessary preventive measures to eliminate or reduce the indicated risk to the so-called acceptable risk. Each workplace should be assessed, and in order to remove the risk and ensure safety, it is necessary to take all measures of collective and individual protection. The act obliges the employer to specify in the work regulations the rules regarding occupational health and safety, including fire protection. Each employee should also be informed about the occupational risk related to the work performed (Siaja et al., 2017). According to Art. $222 \S 2$, the employer must keep a register of work involving the risk of harmful biological agents.

The measures taken in the field of health and safety should be the result of cooperation between the employer and employees. Workers or their representatives should inform the employer of any possible risk in the area of specific workplaces. On the other hand, the employer should agree with them or their representatives on taking actions in the field of occupational health and safety.

The provisions of the Labor Code are confirmed in the Regulation of the Minister of Labor and Social Policy on general health and safety regulations. Also in this act, occupational risk is defined as undesirable events occurring in the work environment that may cause health problems for employees. The work environment is understood as the environment of performing professional duties, which is conditioned by physical, chemical and biological factors (Niciejewska and Kiriliuk, 2020; Weier, 2020). However, the threat is a violation of the proper environmental conditions workplace, which may cause an accident or disease.

According to Art. 227 of the Regulation, the employer is obliged to prepare an appropriate work environment and safe work stations, properly equipped, protecting employees against possible threats and the effects of factors harmful to health, causing occupational diseases, such as other diseases caused by working conditions. Occupational risk assessment should be carried out at all workplaces and for all occupational hazards, however, the legislator provides for separate requirements for certain groups of factors. Detailed regulations on occupational risk assessment for chemical and biological agents, noise and mechanical vibrations as well as manual transport work have been included in numerous regulations.

Pursuant to the indicated legal acts, the employer is obliged to take appropriate preventive measures to eliminate or reduce the probability of the occurrence of hazards in the position. The basic activity is therefore occupational risk assessment, which allows to adjust working conditions by implementing new technical solutions replacing outdated working methods. Each employee must also be informed about the changes introduced and trained in occupational health and safety. The abovementioned legal acts were introduced on the basis of the provisions of the Framework 
Directive (Gorde and Borade, 2019; Directive 89/391/EEC, 1989). In line with the above mentioned regulations and according to the literature (Holubova, 2016) two basic stages can be distinguished in the occupational risk assessment procedure (Górska, 2016):

- the process of analysing occupational risk, which consists of activities consisting in collecting information, identifying threats and estimating threats, consisting in assessing the probability of occurrence of threats and their potential effects,

- determination of admissibility of occupational risk.

\subsection{Legal regulations concerning occupational risk}

Classification of the occupational risk assessment methods at the workplace concerns hazards: physical (related to mechanical factors, noise, vibrations, cold and hot microclimate, lighting, etc.), chemical, biological and psychophysical (Niciejewska and Kiriliuk, 2020). Additionally, the methods of assessing physical and mental stress as well as methods of assessing the risk of musculoskeletal ailments are known (Niciejewska and Klimecka-Tatar, 2018; Pinupong et al., 2020). The methods used by employers include: method according to PN-N-18 002: 2011 standard, Risk Score, PHA, risk graphs. And other methods used less frequently: Risk Assessment Code (RAC), What If, Hazard and Operability Studies (HAZOP), Failure Modes and Effects Analysis (FMEA), FTA- Fault Tree Analysis, Event Tree Analysis (ETA), Cause and Consequence Analysis (CCA), HRA Human Reliability Analysis and many more. All the above-mentioned methods can be divided into deductive (in other words "general to detail" method) and inductive methods (detail to general method).

In the literature on the subject, there is also a division into quantitative and qualitative methods. Quantitative methods analyse the number of data on the frequency and type of accidents at work, hazardous events, occupational diseases, time of exposure to risk factors, etc. However, qualitative methods rely on adjusting the risk to a contractual characterizing value - called risk valuation. These methods are widely described in the literature, also with the specification of the various workplaces and the various risk factors (Knardahl et al., 2017; Pinupong et al., 2020; Tabor, 2018).

\subsection{Methods of assessing physical and mental load}

The literature describes methods that are mainly devoted to the physical and mental load (Harvey et al., 2017; Hulshof et al., 2019; Jasik-Ślęzak and Baryshnikova, 2020; Pałęga et al., 2019; Pinupong et al., 2020). It is a method of assessing energy expenditure based on the research of Lehmann and his students (Spitzer and Hettinger) from the Max Planck Institute in Dortmund, called the Lehmann method. It is a tabular-chronometric method, where the energy expenditure is calculated on the basis of a thorough analysis of all activities performed during 8 hours of work, determining their duration and assigning them energy standards taken from tables specially developed for this purpose. The risk of musculoskeletal disorders that can be assessed by the following methods (Gorde and Borade, 2019; Gómez-Galán et al., 2020; Kirci et al., 2020; Pałęga et al., 2019; Woźny, 2020): Rapid Entire Body Assesment (REBA), Rapid Upper Limb Assessment (RULA), Ovako Working Posture Analysing System (OWAS), Risk Mapping Method, Occupational Repetitive Action Index (OCRA), Job Strain Index (JSI), LMM of key indicators, NOSCH, Key Item Method (KIM), Manual Handling Assessment Charts (MAC), Ergonomic Hazard Identification Checklist. 


\section{RESEARCH METHODS}

The position of the seller may differ to a large extent from the point of view of the place of work, and so it can be distinguished a seller in retail trade (in a small or large grocery store) and a seller in wholesale trade (in large warehouses and trade sectors). A seller in retail trade may work in a large or small store, can also be the owner, hire employees or perform all the above-mentioned activities independently. A seller in wholesale trade is responsible for preparing and executing a wholesale order for goods in a warehouse or warehouse. Such a seller is an intermediary (connection) between the producer and the final buyer of the goods. The sellers, apart from general activities related to the work performed (sale of goods), are also responsible for contact with the customer, negotiations, financial, technical and consulting services. In addition, it is required that an employee in the position of a salesman has the ability to use technical devices (even computer systems, cash registers, cutting and transport tools) (Baryshnikova et al., 2020). Additionally, they should have a very broad knowledge of chemical and biological factors affecting the offered products (this applies in particular to the seller in the grocery store) (Bhullar et al., 2020; Kapustka et al., 2020; McElroy et al., 2020; Pigatto et al., 2020).

Two types of research methods are presented in this paper. The first is the Ergonomic Checkpoint List and the second is the survey method (Ahmadi et al., 2017). Both research, the Ergonomic Checkpoint List and the questionnaire research, were conducted in relation to research on occupational safety and hazards in the work of a grocer seller (with emphasis on work in small enterprises).

The Ergonomic Checkpoint List is a method that was created as a result of efforts to reduce the number of accidents and occupational diseases. The following suggestions can be used to implement corrective actions:

- develop solutions for the modernization of workplaces with the active involvement of employees and their superiors,

- plan and implement improvements as a team,

- $\quad$ use the knowledge and experience of the local work environment,

- use a variety of activities,

- $\quad$ apply the principle of continuous improvement.

Among the most important benefits of using the Ergonomic Checkpoint List is that it brings very quick and measurable results. Improvement of working conditions and safety results in a reduction of accidents at work, a reduced number of occupational diseases, and a smaller number of serious industrial accidents.

\section{RESULTS AND DISCUSSION}

Table 1 presents the Ergonomic Checkpoint List prepared on the basis of information from enterprises and observation of the work of employees on a position of seller in a grocery store - a small grocery store. 
Table 1

The Ergonomic Checkpoint List on a position of seller in a grocery store

\begin{tabular}{|c|c|c|c|c|c|}
\hline No. & CONTROL POINT & Yes & No & Priority & $\mathbf{n} / \mathbf{a}$ \\
\hline \multicolumn{6}{|c|}{ I. STORAGE } \\
\hline 1. & Clean and mark communication routes & & $\mathrm{x}$ & & \\
\hline 2. & $\begin{array}{l}\text { Keep communication routes wide enough to allow two-way } \\
\text { transportation }\end{array}$ & $\mathrm{x}$ & & & \\
\hline 3. & $\begin{array}{l}\text { Keep the communication routes clean. Make sure they } \\
\text { have an even and non-slippery surface - free from } \\
\text { obstacles }\end{array}$ & & & & $\mathrm{x}$ \\
\hline 4. & Provide low slope ramps replacing steps or thresholds & & $\mathrm{x}$ & & \\
\hline 5. & $\begin{array}{l}\text { Plan the working layout to minimize the transport of } \\
\text { production materials }\end{array}$ & & & & $\mathrm{x}$ \\
\hline 6. & $\begin{array}{l}\text { When moving materials / goods, use manual or mechanical } \\
\text { transport carts }\end{array}$ & & $x$ & & \\
\hline 7. & $\begin{array}{l}\text { Use mobile storage racks to avoid unnecessary loading and } \\
\text { unloading }\end{array}$ & & & $\mathrm{x}$ & \\
\hline 8. & $\begin{array}{l}\text { Use multi-level shelves and racks close to the workplace to } \\
\text { minimize manual transport }\end{array}$ & & & $x$ & \\
\hline 9. & $\begin{array}{l}\text { Use mechanical devices for lifting, lowering and moving } \\
\text { heavy materials/products }\end{array}$ & & $\mathrm{x}$ & & \\
\hline 10. & $\begin{array}{l}\text { Reduce manual products transport using various } \\
\text { mechanical means of transport (conveyors, lifts, } \\
\text { transporters) }\end{array}$ & & & & $\mathrm{x}$ \\
\hline 11. & $\begin{array}{l}\text { Divide heavy loads into lighter packages, containers for } \\
\text { easier transport }\end{array}$ & & & & $\mathrm{x}$ \\
\hline 12. & $\begin{array}{l}\text { Use the appropriate handles for carrying the containers and } \\
\text { transport boxes }\end{array}$ & $\mathrm{x}$ & & & \\
\hline 13. & $\begin{array}{l}\text { Moving heavy elements should take place at the same } \\
\text { working height }\end{array}$ & $\mathrm{x}$ & & & \\
\hline 14. & $\begin{array}{l}\text { Eliminate tasks that require body bending and turning } \\
\text { during transport }\end{array}$ & $\mathrm{x}$ & & & \\
\hline 15. & $\begin{array}{l}\text { When handling products by hand, their should be kept } \\
\text { close to the body }\end{array}$ & & & $\mathrm{x}$ & \\
\hline 16. & $\begin{array}{l}\text { Alternate between physically heavy and lighter work to } \\
\text { reduce }\end{array}$ & & & $\mathrm{x}$ & \\
\hline 17. & Provide a convenient location for waste & $\mathrm{x}$ & & & \\
\hline \multicolumn{6}{|c|}{ II. HAND TOOLS } \\
\hline 18. & When choosing tools, be guided by their specialized use & & & $\mathrm{x}$ & \\
\hline 19. & $\begin{array}{l}\text { Provide safe electrical tools and make sure they are } \\
\text { properly secured }\end{array}$ & & & $\mathrm{x}$ & \\
\hline 20. & $\begin{array}{l}\text { If possible, use hanging tools for repetitive operations at the } \\
\text { workplace }\end{array}$ & $\mathrm{x}$ & & & \\
\hline 21. & Use vices and clamps to hold materials or workpieces & & & & $\mathrm{x}$ \\
\hline 22. & Provide support to the elbows when using precision tools & & & & $\mathrm{x}$ \\
\hline 23. & Minimize the weight of tools (except for specialized tools) & & & & $\mathrm{x}$ \\
\hline 24. & Provide hand tools with correct handles for easy handling & & $\mathrm{x}$ & & \\
\hline 25. & $\begin{array}{l}\text { Provide hand tools with a firm, non-slippery grip to prevent } \\
\text { accidental hand injuries or release from hand }\end{array}$ & $\mathrm{x}$ & & & \\
\hline
\end{tabular}




\begin{tabular}{|c|c|c|c|c|}
\hline 26. & $\begin{array}{l}\text { Provide properly insulated tools to resist burns or electric } \\
\text { shock }\end{array}$ & $x$ & & \\
\hline 27. & $\begin{array}{l}\text { Minimize the effects of vibration and noise emitted by } \\
\text { electric hand tools }\end{array}$ & $\mathrm{x}$ & & \\
\hline 28. & Provide permanent (designated) storage for tools & $x$ & & \\
\hline 29. & $\begin{array}{l}\text { Regularly check the technical condition of the tools and } \\
\text { maintain them frequently }\end{array}$ & & $\mathrm{x}$ & \\
\hline 30. & Train employees before allowing them to use electric tools & & $x$ & \\
\hline 31. & $\begin{array}{l}\text { When working with power tools, provide employees with } \\
\text { sufficient space for a stable working position }\end{array}$ & $\mathrm{x}$ & & \\
\hline \multicolumn{5}{|c|}{ III. SAFETY IN MACHINE OPERATION } \\
\hline 32. & $\begin{array}{l}\text { Design machine controls to prevent accidental starting or } \\
\text { shutting down of the machine }\end{array}$ & $\mathrm{x}$ & & \\
\hline 33. & $\begin{array}{l}\text { Add clearly visible and easy-to-use emergency controls (in } \\
\text { the operator's natural position) }\end{array}$ & & & $\mathrm{x}$ \\
\hline 34. & $\begin{array}{l}\text { Mark clear controls of machines and equipment, so that it } \\
\text { can be easily distinguished to avoid operating error }\end{array}$ & & & $\mathrm{x}$ \\
\hline 35. & $\begin{array}{l}\text { Make sure the operator has clear visual and manual access } \\
\text { to all controls }\end{array}$ & & & $\mathrm{x}$ \\
\hline 36. & $\begin{array}{l}\text { Where it is essential to follow the sequence of machine } \\
\text { controls, provide clear operating instructions }\end{array}$ & & & $\mathrm{x}$ \\
\hline 37. & Use best practices when designing control devices & & & $\mathrm{x}$ \\
\hline 38 & $\begin{array}{l}\text { To facilitate operation limit the number of control pedals, } \\
\text { and adjust them for easy use }\end{array}$ & & & $\mathrm{x}$ \\
\hline 39. & $\begin{array}{l}\text { Use displays and controls that are easy to distinguish and } \\
\text { read }\end{array}$ & & & $\mathrm{x}$ \\
\hline 40. & Use appropriate signs and colours on displays (unified) & $\mathrm{x}$ & & \\
\hline 41. & Use symbols only when they are understood by everyone & $\mathrm{x}$ & & \\
\hline 42. & $\begin{array}{l}\text { Add labels and signs only in visible places (understandable } \\
\text { and legible) }\end{array}$ & $\mathrm{x}$ & & \\
\hline 43. & $\begin{array}{l}\text { Use warning signs against risks with a clearly defined level } \\
\text { of risk }\end{array}$ & & $\mathrm{x}$ & \\
\hline 44. & $\begin{array}{l}\text { Use the tools and handles to operate machinery in a stable, } \\
\text { safe and effective manner }\end{array}$ & $\mathrm{x}$ & & \\
\hline 45. & Purchase machines that meet the safety criteria & $x$ & & \\
\hline 46. & $\begin{array}{l}\text { Use appropriate barriers to prevent worker hands from } \\
\text { getting into hazardous parts }\end{array}$ & $\mathrm{x}$ & & \\
\hline 47. & $\begin{array}{l}\text { Use covers or barriers that prevent contact with the moving } \\
\text { parts of the machine }\end{array}$ & & & $\mathrm{x}$ \\
\hline 48. & $\begin{array}{l}\text { Use interlocks to prevent workers from reaching dangerous } \\
\text { places while the machine is in operation }\end{array}$ & $\mathrm{x}$ & & \\
\hline 49. & $\begin{array}{l}\text { Establish safe procedures for driving forklifts and proper } \\
\text { training for employees }\end{array}$ & & & $\mathrm{x}$ \\
\hline 50. & $\begin{array}{l}\text { Provide regular inspection, cleaning and maintenance of } \\
\text { machines (and power cables) }\end{array}$ & & $x$ & \\
\hline \multicolumn{5}{|c|}{ VI. DESIGN OF A WORKPLACE } \\
\hline 51. & $\begin{array}{l}\text { Provide working height adjustment for each station (working } \\
\text { height at elbow height or slightly lower) }\end{array}$ & $\mathrm{x}$ & & \\
\hline 52. & $\begin{array}{l}\text { Make sure your work area is comfortable for shorter } \\
\text { workers }\end{array}$ & $\mathrm{x}$ & & \\
\hline 53. & Make sure the work area is comfortable for taller workers & $x$ & & \\
\hline
\end{tabular}




\begin{tabular}{|c|c|c|c|c|}
\hline 54. & $\begin{array}{l}\text { Place the most-used tools, gauges, and materials within } \\
\text { easy reach }\end{array}$ & $\mathrm{x}$ & & \\
\hline 55. & $\begin{array}{l}\text { Provide a stable, multi-functional work surface at every } \\
\text { workplace }\end{array}$ & $\mathrm{x}$ & & \\
\hline 56. & $\begin{array}{l}\text { Make sure that employees work in a stable position (evenly } \\
\text { distributed body weight) at an appropriate distance from the } \\
\text { body }\end{array}$ & & $\mathrm{x}$ & \\
\hline 57. & $\begin{array}{l}\text { Organize work so that employees change positions from } \\
\text { sitting to standing as often as possible }\end{array}$ & $\mathrm{x}$ & & \\
\hline 58. & $\begin{array}{l}\text { Provide employees working in a standing position to use } \\
\text { chairs for temporary rest }\end{array}$ & $\mathrm{x}$ & & \\
\hline 59. & $\begin{array}{l}\text { Provide employees working in a seated position adjustable } \\
\text { chairs with backrest }\end{array}$ & & & $\mathrm{x}$ \\
\hline 60. & $\begin{array}{l}\text { Provide a sufficient height of the computer station with good } \\
\text { reach to peripheral devices }\end{array}$ & $\mathrm{x}$ & & \\
\hline 61. & $\begin{array}{l}\text { Provide regular eye examinations and glasses for } \\
\text { employees working at the monitor }\end{array}$ & $\mathrm{x}$ & & \\
\hline 62 & $\begin{array}{l}\text { Provide a solid and stable base and sufficiently safe } \\
\text { conditions for working at height }\end{array}$ & $\mathrm{x}$ & & \\
\hline 63. & $\begin{array}{l}\text { Increase the safety and comfort of driving in the cabs of } \\
\text { vehicles used at the workplace }\end{array}$ & & & $\mathrm{x}$ \\
\hline \multicolumn{5}{|c|}{ V. WORKPLACE LIGHTING } \\
\hline 64. & Increase the use of daylight & $\mathrm{x}$ & & \\
\hline 65. & Use light colours for walls and ceilings to improve comfort & $\mathrm{x}$ & & \\
\hline 66. & $\begin{array}{l}\text { Provide sufficient lighting in all rooms where work is carried } \\
\text { out (office, warehouse, staircase, etc.) }\end{array}$ & $x$ & & \\
\hline 67. & $\begin{array}{l}\text { Apply uniform lighting to the workstation to minimize } \\
\text { changes in brightness }\end{array}$ & & $\mathrm{x}$ & \\
\hline 68. & $\begin{array}{l}\text { Provide sufficient lighting for employees to work efficiently } \\
\text { and comfortably }\end{array}$ & & $\mathrm{x}$ & \\
\hline 69. & Use local lighting for precision and control work & $\mathrm{x}$ & & \\
\hline 70. & $\begin{array}{l}\text { Adjust the lighting position to eliminate direct or indirect } \\
\text { glare }\end{array}$ & $x$ & & \\
\hline 71. & $\begin{array}{l}\text { Customize the appropriate screens for positions with focus } \\
\text { and continued attention requirement }\end{array}$ & & $\mathrm{x}$ & \\
\hline 72. & $\begin{array}{l}\text { Take care of the maintenance of light sources and clean } \\
\text { windows }\end{array}$ & $\mathrm{x}$ & & \\
\hline \multicolumn{5}{|c|}{ VI. WORK SPACE } \\
\hline 73. & $\begin{array}{l}\text { Provide the worker with adequate protection against high } \\
\text { temperatures }\end{array}$ & $\mathrm{x}$ & & \\
\hline 74. & $\begin{array}{l}\text { Provide the worker with adequate protection against low } \\
\text { temperatures }\end{array}$ & $\mathrm{x}$ & & \\
\hline 75. & Insulate sources of heat or cold in production processes & $x$ & & \\
\hline 76. & Use effective local ventilators that ensure safe operation & & $\mathrm{x}$ & \\
\hline 77. & Increase the use of natural ventilation (airing) & $x$ & & \\
\hline 78. & $\begin{array}{l}\text { Use air conditioning (if indoors) for the comfort and health } \\
\text { of employees }\end{array}$ & $\mathrm{x}$ & & \\
\hline 79. & $\begin{array}{l}\text { Ensure good air quality in the room by proper operation of } \\
\text { the ventilation systems }\end{array}$ & & $\mathrm{x}$ & \\
\hline 80. & $\begin{array}{l}\text { Keep the workplace in a proper order to increase the } \\
\text { efficiency and comfort of employees }\end{array}$ & $x$ & & \\
\hline
\end{tabular}




\begin{tabular}{|c|c|c|c|c|c|}
\hline 81. & $\begin{array}{l}\text { Provide a sufficient number of fire extinguishers in marked } \\
\text { places, provide training in use }\end{array}$ & $\mathrm{x}$ & & & \\
\hline 82. & $\begin{array}{l}\text { Follow the principles of recycling to better use resources } \\
\text { and protect the environment }\end{array}$ & $\mathrm{x}$ & & & \\
\hline 83. & Mark escape routes and keep them clean & $\mathrm{x}$ & & & \\
\hline 84. & $\begin{array}{l}\text { Develop and update an evacuation plan to ensure a safe } \\
\text { and quick evacuation }\end{array}$ & & & $\mathrm{x}$ & \\
\hline \multicolumn{6}{|c|}{ VII. HAZARDOUS FACTORS } \\
\hline 85. & Isolate or mute noisy machines or loud machine parts & & $\mathrm{x}$ & & \\
\hline 86. & $\begin{array}{l}\text { Maintain tools and machinery properly to minimize noise } \\
\text { from wear }\end{array}$ & & $\mathrm{x}$ & & \\
\hline 87. & $\begin{array}{l}\text { Make sure that the noise does not interfere with verbal } \\
\text { communication and receiving sound signals (e.g. warning } \\
\text { signals) }\end{array}$ & $\mathrm{x}$ & & & \\
\hline 88. & Reduces vibrations affecting employees & & $\mathrm{x}$ & & \\
\hline 89. & $\begin{array}{l}\text { Purchase portable lighting equipment that is well insulated } \\
\text { to protect against electric shock and heat injury }\end{array}$ & & $\mathrm{x}$ & & \\
\hline 90. & Take care of the safety of the electrical installation & $\mathrm{x}$ & & & \\
\hline 91. & Properly label containers with hazardous substances & & & $\mathrm{x}$ & \\
\hline 92. & Use personal protective equipment & & $\mathrm{x}$ & & \\
\hline 93. & $\begin{array}{l}\text { Define enclosed spaces requiring entry permits, make them } \\
\text { available only to trained workers }\end{array}$ & $\mathrm{x}$ & & & \\
\hline 94. & $\begin{array}{l}\text { Use protective processes against biological hazards, isolate } \\
\text { potential contaminated areas }\end{array}$ & & $\mathrm{x}$ & & \\
\hline 95. & $\begin{array}{l}\text { Provide sanitary facilities, take care of hygiene and } \\
\text { cleanliness }\end{array}$ & $\mathrm{x}$ & & & \\
\hline 96. & Prepare hygienic and clean rooms for eating and drinking & $\mathrm{x}$ & & & \\
\hline 97. & Provide rest rooms during breaks & $\mathrm{x}$ & & & \\
\hline 98. & Provide access to sanitary aid & $\mathrm{x}$ & & & \\
\hline 99. & Provide facilities for meetings and training & $\mathrm{x}$ & & & \\
\hline 100. & $\begin{array}{l}\text { Clearly and legibly mark areas where application of } \\
\text { personal protective equipment (PPE) is required }\end{array}$ & & & & $\mathrm{x}$ \\
\hline 101. & $\begin{array}{l}\text { Provide employees with personal protective equipment - } \\
\text { only those that provide protection }\end{array}$ & & $\mathrm{x}$ & & \\
\hline 102. & $\begin{array}{l}\text { Provide employees with training on how to use personal } \\
\text { protective equipment }\end{array}$ & $\mathrm{x}$ & & & \\
\hline 103. & $\begin{array}{l}\text { Monitor the use of personal protective equipment - where } \\
\text { necessary }\end{array}$ & & & $\mathrm{x}$ & \\
\hline 104. & Make sure that PPE are properly maintained and stored & & $\mathrm{x}$ & & \\
\hline 105. & $\begin{array}{l}\text { Provide a suitable place for cleaning and storage of } \\
\text { protective equipment }\end{array}$ & & $\mathrm{x}$ & & \\
\hline \multicolumn{6}{|c|}{ VIII. WORK ORGANIZATION } \\
\hline 106. & $\begin{array}{l}\text { Consult work organization problems daily - involve all } \\
\text { employees }\end{array}$ & & & $\mathrm{x}$ & \\
\hline 107. & Consult with employees when preparing a work plan & $\mathrm{x}$ & & & \\
\hline 108. & Involve employees in designing workplace improvements & $\mathrm{x}$ & & & \\
\hline 109. & $\begin{array}{l}\text { Consult with employees on changes in work organization } \\
\text { and changes aimed at work safety improvement }\end{array}$ & & & $\mathrm{x}$ & \\
\hline 110. & $\begin{array}{l}\text { Inform employees how they should do their job, reward } \\
\text { them for correct performance }\end{array}$ & & & $x$ & \\
\hline 111. & Organize employee training in order to increase employee & & $\mathrm{x}$ & & \\
\hline
\end{tabular}




\begin{tabular}{|c|c|c|c|c|}
\hline & $\begin{array}{l}\text { responsibility for the effects of their work in the overall } \\
\text { activity }\end{array}$ & & & \\
\hline 112. & $\begin{array}{l}\text { Plan training courses for your employees on safe and more } \\
\text { efficient work }\end{array}$ & & $\mathrm{x}$ & \\
\hline 113. & Provide training for employees using computer systems & $\mathrm{x}$ & & \\
\hline 114. & Provide easy communication and mutual support & $\mathrm{x}$ & & \\
\hline 115. & Assign tasks according to employee qualifications & $\mathrm{x}$ & & \\
\hline 116. & $\begin{array}{l}\text { Create working groups for teamwork and shared } \\
\text { responsibility }\end{array}$ & & $\mathrm{x}$ & \\
\hline 117. & $\begin{array}{l}\text { Use the ideas of managers and employees to solve } \\
\text { organizational problems }\end{array}$ & $\mathrm{x}$ & & \\
\hline 118. & $\begin{array}{l}\text { Modify employee tasks to make them more varied and } \\
\text { interesting }\end{array}$ & $x$ & & \\
\hline 119. & Organize material flow between stations to avoid downtime & $\mathrm{x}$ & & \\
\hline 120. & Schedule a time to the workplace cleaning & $\mathrm{x}$ & & \\
\hline 121. & $\begin{array}{l}\text { Plan numerous short breaks for computer workstations } \\
\text { workers }\end{array}$ & $\mathrm{x}$ & & \\
\hline 122. & $\begin{array}{l}\text { Provide favourable conditions for employees' physical } \\
\text { activity (before, during or after work) }\end{array}$ & $\mathrm{x}$ & & \\
\hline 123. & Involve employees to look for work improvements & $\mathrm{x}$ & & \\
\hline 124. & $\begin{array}{l}\text { Support migrant workers, provide them with training and } \\
\text { assistance }\end{array}$ & $x$ & & \\
\hline 125. & Provide young workers with support from older workers & $\mathrm{x}$ & & \\
\hline 126. & Prepare areas, offices for the needs of disabled workers & $\mathrm{x}$ & & \\
\hline 127. & $\begin{array}{l}\text { Take care of the safety of pregnant women and nursing } \\
\text { mothers }\end{array}$ & & & $\mathrm{x}$ \\
\hline 128. & Take care of the safety of older workers & $\mathrm{x}$ & & \\
\hline 129. & $\begin{array}{l}\text { Adapt workplaces to the preferences of employees' cultural } \\
\text { differences }\end{array}$ & $\mathrm{x}$ & & \\
\hline 130. & $\begin{array}{l}\text { Involve managers and employees to implement } \\
\text { improvements aimed at reducing occupational risk }\end{array}$ & & & $\mathrm{x}$ \\
\hline 131. & $\begin{array}{l}\text { Develop contingency procedures to ensure proper } \\
\text { operation in an emergency }\end{array}$ & & & $\mathrm{x}$ \\
\hline 132. & $\begin{array}{l}\text { Apply ways to improve your workplace by using the } \\
\text { experience of others }\end{array}$ & $\mathrm{x}$ & & \\
\hline
\end{tabular}

Source: own study based on (Górska, 2016; Helali, 2009)

On the basis of the data presented in Table 1 of the Ergonomic Checkpoint List, it can be noticed that the actual position of a salesman in a grocery store is associated with exposure of health to numerous occupational risk factors. Through commonly known physical, mechanical, through biological and chemical factors, not forgetting, of course, psycho-social factors. These factors cause numerous threats during the performance of professional activities. In order to characterize the risks, a short (general) survey was carried out in order to identify the most common causes of accidents and hazardous events in the seller's workplace.

The survey on the risks associated with working as a salesman (warehouse) was conducted in December 2019 in grocery stores of a well-known brand. According to the research, all employees are women of various age groups (mainly between 30 and 45 ), with primary or secondary education. The questionnaire contained questions 
about working conditions and related ailments. For the sake of clarity of data presentation, only the most important results are discussed.

The first question concerned work-related pain in the employees. The respondents had a choice of four answers: back pain, neck pain, pain in hands and leg pain. The distribution of answers is presented in Fig. 1.

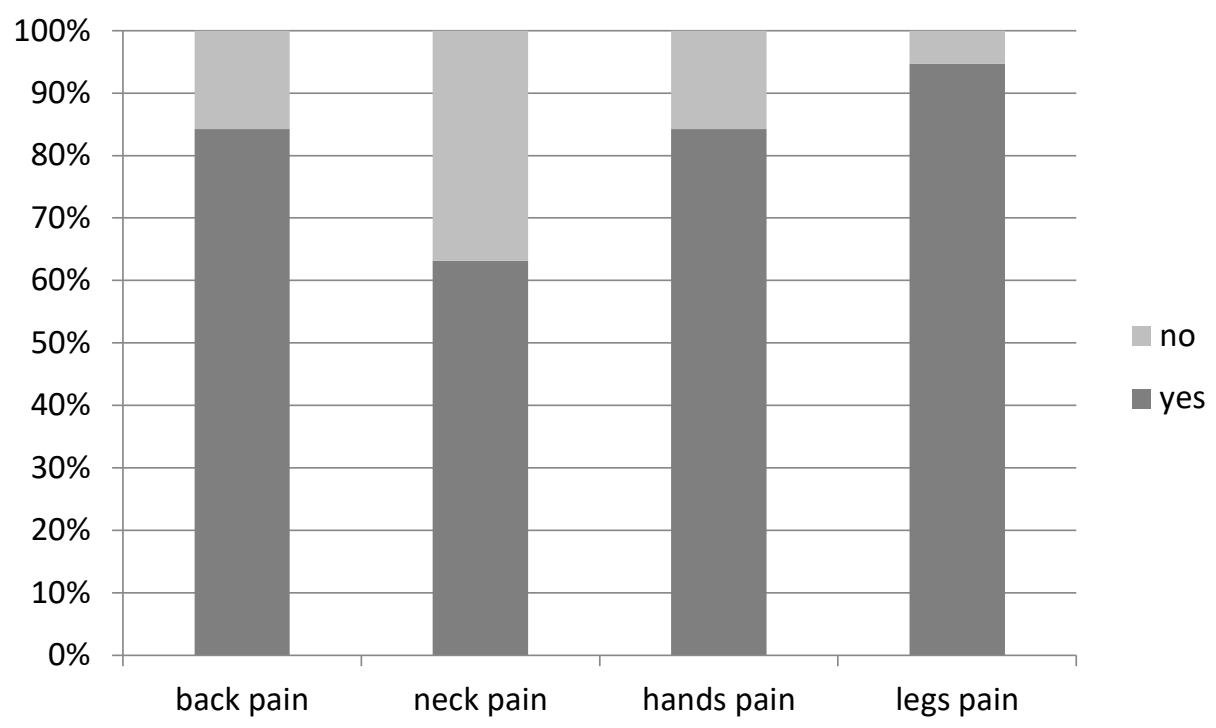

Fig. 1. Distribution of answers to the question: What ailments do you experience during work? Source: own study

As it is shown in Fig. 1, most employees experience various types of pain during their work and the most common type of ailment is pain in the arms and legs (94.7\%).

The next question was related to the use of devices that facilitate work when moving goods (Fig. 2). The respondents mostly answered that there was no possibility of applying such facilities (apart from the transfer of goods from the supplier to the warehouse). And only in one of the stores the sellers had access to a hand truck.

Excessive load on the musculoskeletal system is the most common risk in the workplace. Despite the increasingly frequent introduction of mechanization and automation of processes, it is not possible to completely eliminate them. This applies in particular to such branches of the economy as service activities, construction and retail trade. The lack of appropriate devices enabling the reduction of burdens is the more visible the smaller the economic entity. 


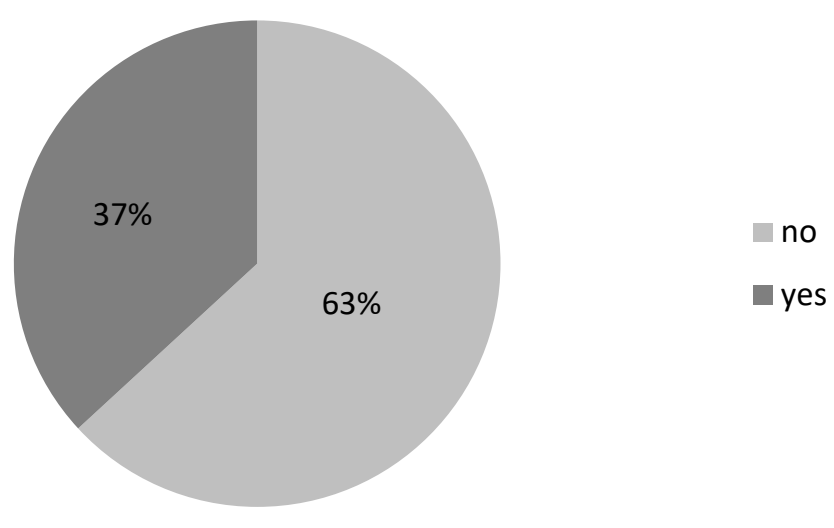

Fig.2. Distribution of answers to the question: Are there any means of transport in the store that facilitate work?

Source: own study

Another question was: what elements of the workplace do not meet the requirements? The respondents had the following answers to choose from: insufficient lighting, no suitable seat, too small work space, tight aisles between shelves. The distribution of answers to this question is presented in Figure 3. As it can be seen, the biggest problem is the lack of a suitable seat (often it is completely absent - work is done in a standing position), and the smallest problem is insufficient lighting.

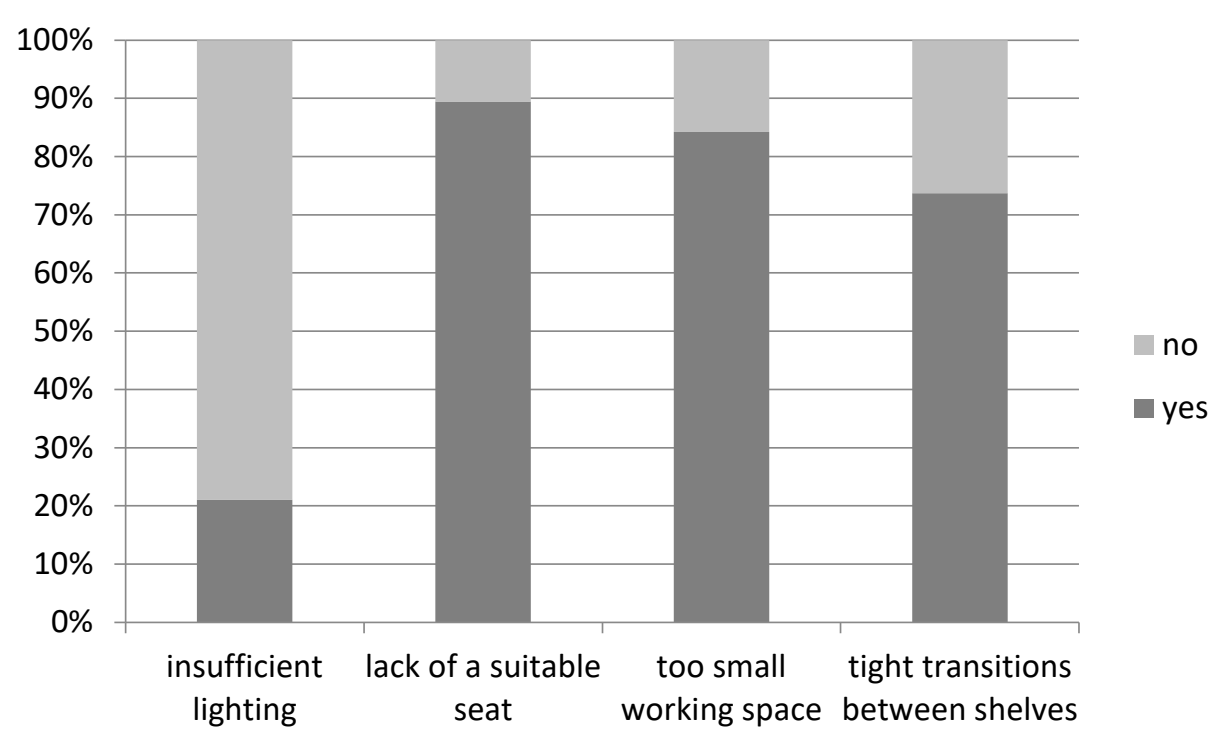

Fig. 3. Distribution of answers to the question: what elements of the workplace do not meet the Source: own study requirements?

The last of the analysed questions concerned psychosocial risks and was: what types of psychosocial risks are present at your workplace? The respondents could choose from the following answers: excess of duties, stress related to aggressive clients, monotony of work. The distribution of answers to this question is shown in Figure 4. 


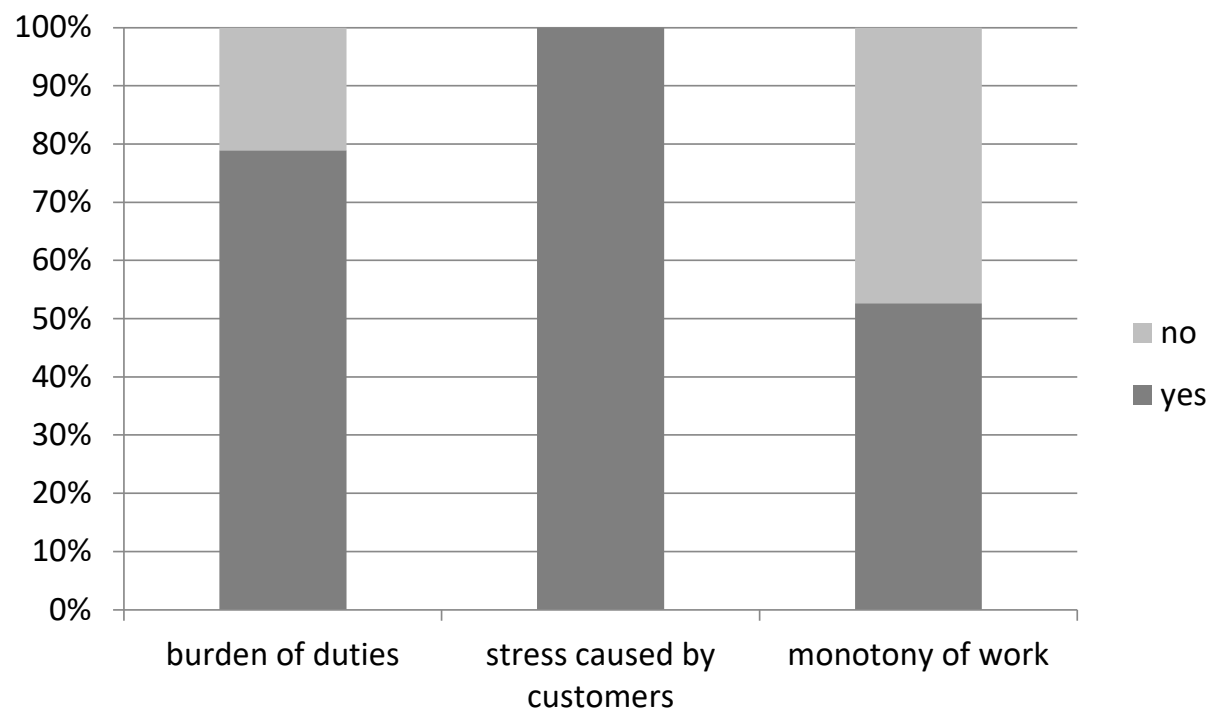

Fig. 4. Distribution of answers to the question: what psychosocial risks are present at your workplace?

Source: own study

\section{SUMMARY}

Due to the very high load on the musculoskeletal system, work in a small grocery store is reluctantly undertaken. Although the position variability during work is ensured, a very high load on the legs (working in a standing position) and hands (manual transfer of goods) is one of the factors causing numerous diseases and pain. Both when analysing the responses in the Ergonomic Checkpoint List and analysing the responses during the survey, it is easy to observe that it is pain in the extremities that are the most frequently indicated ailments.

Additionally, as shown by the presented research results, employers should demonstrate much greater care for safety factors in the work environment. Among the factors indicated as safety measures, it is often observed that the conditions of the working environment do not match the requirements, i.e. there is often no suitable seat for rest, the working space is too small, and the aisles between shelves do not ensure the safety of employees (and customers) both during work (shopping) and in emergency situations. Therefore, it is recommended to improve the working conditions of the seller in small grocery stores based on the presented Ergonomic Checkpoint List.

\section{REFERENCES}

Ahmadi, M., Zakerian, S. A., Salmanzadeh, H., 2017. Prioritizing the ILO/IEA Ergonomic Checkpoints' measures; a study in an assembly and packaging industry, International Journal of Industrial Ergonomics, 59, 54-63. DOI: 10.1016/j.ergon.2017.03.002

Baryshnikova, N., Kiriliuk, O., Klimecka-Tatar, D., 2020. Management approach on food export expansion in the conditions of limited internal demand, Polish Journal of Management Studies, 21(2), 101-114. DOI: 10.17512/pjms.2020.21.2.08

Bhullar, M. S., Monge-Brenes, A., Perry, B., Nabwiire, L., Laury-Shaw, A., 2020. Determining the potential food safety risks associated with dropped produce on 
floor surfaces in grocery stores, Journal of Food Protection, Advance online publication. DOI: 10.4315/JFP-20-136

Directive 89/391/EEC, 1989. Directive 89/391/EEC - OSH "Framework Directive": of 12 June 1989 on the introduction of measures to encourage improvements in the safety and health of workers at work - "Framework Directive", Retrieved from https://osha.europa.eu/pl/legislation/directives/the-osh-framework-directive/1"

Eurostat Report, 2020. Volume of retail trade up by $17.8 \%$ in euro area.

Gorde, M. S., Borade, A. B., 2019. The Ergonomic Assessment of Cycle Rickshaw Operators Using Rapid Upper Limb Assessment (Rula) Tool and Rapid Entire Body Assessment (Reba) Tool, System Safety: Human - Technical Facility Environment, 1(1), 219-225. DOI: 10.2478/czoto-2019-0028

Gómez-Galán, M., Callejón-Ferre, Á.-J., Pérez-Alonso, J., Díaz-Pérez, M., CarrilloCastrillo, J.-A., 2020. Musculoskeletal Risks: Rula Bibliometric Review, International Journal of Environmental Research and Public Health, 17(12). DOI: 10.3390/ijerph17124354

Górska, E., 2016. Metody oceny ryzyka zawodowego, Oficyna Wydawnicza Politechniki Warszawskiej, Warszawa.

Harvey, S.B., Modini, M., Joyce, S., Milligan-Saville, J.S., Tan, L., Mykletun, A., Mitchell, P.B., 2017. Can work make you mentally ill? A systematic meta-review of work-related risk factors for common mental health problems, Occupational and Environmental Medicine, 74(4), 301-310. DOI: 10.1136/oemed-2016-104015

Helali, F., 2009. Using ergonomics checkpoints to support a participatory ergonomics intervention in an industrially developing country (IDC)-a case study, International Journal of Occupational Safety and Ergonomics: JOSE, 15(3), 325-337. DOI: 10.1080/10803548.2009.11076811

Holubova, V., 2016. Integrated safety management systems, Polish Journal of Management Studies, 14(1), 106-118. DOI: 10.17512/pjms.2016.14.1.10

Hulshof, C.T.J., Colosio, C., Daams, J.G., Ivanov, I.D., Prakash, K.C., Kuijer, P.P. F. M., Frings-Dresen, M.H.W., 2019. Who/ilo work-related burden of disease and injury: Protocol for systematic reviews of exposure to occupational ergonomic risk factors and of the effect of exposure to occupational ergonomic risk factors on osteoarthritis of hip or knee and selected other musculoskeletal diseases. Environment International, 125, 554-566. DOI: 10.1016/j.envint.2018.09.053

Jasik-Ślęzak, J., Baryshnikova, N., 2020. The Effect of Static Physical Work on the Work Safety, System Safety: Human - Technical Facility - Environment, 2(1), 4754. DOI: 10.2478/czoto-2020-0007

Kapustka, K., Ziegmann, G., Klimecka-Tatar, D., Ostrega, M., 2020. Identification of health risks from harmful chemical agents - review concerning bisphenol a in workplace, Production Engineering Archives, 26(2), 45-49. DOI: 10.30657/pea.2020.26.10

Kirci, B. K., Ensari Ozay, M., Ucan, R., 2020. A Case Study in Ergonomics by Using REBA, RULA and NIOSH Methods: Logistics Warehouse Sector in Turkey, Hittite Journal of Science \& Engineering, 7(4), 257-264. DOI: 10.17350/HJSE19030000194

Knardahl, S., Johannessen, H. A., Sterud, T., Härmä, M., Rugulies, R., Seitsamo, J., Borg, V., 2017. The contribution from psychological, social, and organizational work factors to risk of disability retirement: $A$ systematic review with metaanalyses, BMC Public Health, 17(1), 176. DOI: 10.1186/s12889-017-4059-4 
McElroy, E., Duong, N., Labiste, C., 2020. Safety Recommendations for Grocery Store Workers and Employers during the COVID-19 Pandemic, Advance online publication. DOI: 10.13140/RG.2.2.23552.05121

Niciejewska, M., Kiriliuk, O., 2020. Occupational health and safety management in "small size" enterprises, with particular emphasis on hazards identification, Production Engineering Archives, 26(4), 195-201. DOI: 10.30657/pea.2020.26.34

Niciejewska, M., Klimecka-Tatar, D., 2018. Health problems among employees in small enterprises as a result of improper OHS management, MATEC Web of Conferences, 183, 1012. DOI: 10.1051/matecconf/201818301012

Pałęga, M., Rydz, D., Wojtyto, D., Arbuz, A., 2019. Ergonomic Evaluation of Working Position Using the Reba Method - Case Study, System Safety: Human - Technical Facility - Environment, 1(1), 61-68. DOI: 10.2478/czoto-2019-0008

Pigatto, P. D., Ronchi, A., Guzzi, G., 2020. Chemical Exposure, Risk of Multiple Chemical Sensitivity, and Occupational Safety, Safety and Health at Work, 11(3), 383-384. DOI: 10.1016/j.shaw.2020.05.006

Pinupong, C., Jalayondeja, W., Mekhora, K., Bhuanantanondh, P., Jalayondeja, C., 2020. The Effects of Ramp Gradients and Pushing-Pulling Techniques on Lumbar Spinal Load in Healthy Workers, Safety and Health at Work, 11(3), 307-313. DOI: 10.1016/j.shaw.2020.05.001

Report 2020. Who is the largest employer in retail trade in Poland. Retrieved from http://www.portalspozywczy.pl/handel/wiadomosci/kto-jest-najwiekszympracczości-w-handlu-detaliczny-w-polsce,140169.html

Rozporządzenie Ministra Pracy i Polityki Socjalnej, 1997. Rozporządzenie Ministra Pracy i Polityki Socjalnej w sprawie ogólnych przepisów bezpieczeństwa i higieny pracy z dnia 26 września 1997. Dz.U. 1997 Nr 129 Poz. 844 z późn. zmianami.

Sas, A., 2020. Number of retail chains in Poland 2020, by sector. Retrieved from https://www.statista.com/statistics/642185/retail-chains-number-by-sector-poland/

Siaja, P., Woźny, A., Pacana, A., Dobosz, M., 2017. Additional components of risk assessment and their impact on the probability parameter, Production Engineering Archives, 14, 11-14. DOI: 10.30657/pea.2017.14.03

Tabor, J., 2018. A grey-based decision-making approach to the improvement of OHS management system, Polish Journal of Management Studies, 18(1), 389-402. DOI: $10.17512 /$ pjms.2018.18.1.29

Weier, M. H., 2020. The Association between Occupational Exposure to Hand-Arm Vibration and Hearing Loss: A Systematic Literature Review, Safety and Health at Work, 11(3), 249-261. DOI: 10.1016/j.shaw.2020.04.003

Woźny, A., 2020. Selected problems of managing work safety - case study, Production Engineering Archives, 26(3), 99-103. DOI: 10.30657/pea.2020.26.20 